\title{
The Effect of the War on the Loan and Shelf Division of the University of California Library
}

Miss Steedman is acting chief of the Loan and Shelf Division of the General Library of the University of California.

$\mathrm{T}$

HE WAR has brought many changes to the University of California, changes which are reflected by the library in new problems and added functions. The loan and shelf division of the general library, including the main loan desk, the reserved book room, and the rental service, has felt these changes in a number of ways.

The first and most striking effect is the drop in circulation. In our last normal year, 1939-40, the circulation at the service desks was I,I5I,59I. In the year ending June 1943, the figures had dropped over 50 per cent to 513,621. From all indications the current year will show an even greater decline in spite of the present three-term system of instruction, which necessitates running the library on full schedule for the entire year. This drop in circulation may be attributed not only to the decrease in registration from 16,228 in the fall of 1939 to approximately 9000 , including Army students, in the fall of I943, but also to several other factors. There has been a change in emphasis, due to the war, from the liberal arts courses, with long reading lists and term papers, to scientific and technical courses, which use a text and a laboratory manual. Al- though the Army and Navy boys do use the library for supplementary reading, they have been supplied with most necessary books by the government. Furthermore, the Army Specialized Training Units are kept too busy with their own intensive programs to do a great deal of collateral or general interest reading. In addition to these factors, we have received the impression that the majority of regular students are not interested in studying. This is a trend difficult to illustrate with concrete examples, but it is a feeling shared not only by the members of our staff but also by various members of the faculty and may be attributed to the feeling of uncertainty due to the war which is so prevalent in all aspects of present-day life.

One would imagine from this decrease in circulation that the loan and shelf division would be relaxing after its former activity and that a personnel problem would not exist. Such is not the case. In the first place, the budget was cut sharply this year, curtailing the amount of student help we have been able to hire. It is not only in amount but especially in quality and experience of help that we have suffered. The division formerly used college boys for all paging and shelving. The boys used to remain for several years, so that we always had a 
working nucleus of experienced help who could carry many of the routine tasks of the division. Our last old boy, classified ${ }_{4} \mathrm{~F}$ and attending law school, had been with us since 1938. When he left early in February of this year, our last link with the old regime ended. We now use college girls for the tasks formerly handled by boys and, although we have a few who are careful, accurate, loyal, and dependable, most of them lack a sense of responsibility and must be supervised constantly. Furthermore, they are not physically able to do the work that boys tackled with vigor. Paging for more than two hours at a time, shelving, and moving. heavy trucks of books is too difficult and tiring for the average girl, and we find that it requires almost twice the number of girls to produce the amount of work turned out by boys. In view of the fact that the starting rate of pay is fifty cents an hour compared with forty cents an hour paid formerly, one can see results are not commensurate with expenditure.

\section{Staff Turnover}

Our greatest personnel problem, however, is turnover. We try to keep a staff for the main loan desk and reserved book room of about fifty-five student assistants. We have hired sixty-six students since June I943, but during that same period eighty-six left, including forty of the sixtysix hired in that time. We have ten "old hands" on the staff who have been with us as long as a year; we used to consider it took at least a year to train a good page, and the more responsible positions, such as desk attendant, were not assigned to students without two or three years of experience. This lack of experienced student assistants has resulted in the professional members of the staff taking over much of the minor supervisory work formerly carried by boys with from three to five years' experience in the division. Not only that, but the professional assistants have not been too proud to do some paging and shelving themselves on those occasions, such as vacation week, when students can be neither bribed nor begged to work.

Nor does our trouble cease with student assistants. For the year ending in June 1943, we had five full-time clerical positions in the division, two in the reserved book room and three at the loan desk. In order to fill those five positions last year, fourteen people were engaged, but there were thirteen resignations; so far this year five have been engaged and six have resigned. We are just holding our own, but the loss of time and energy spent in training new assistants has been great.

\section{Crowded Stacks}

Another result of wartime conditions shows in the overcrowded state of the stack. Although there is a vacant area in the center of the stack-block which is to be filled in with steel stack, this work cannot be done under present conditions. Meanwhile, nothing halts the output of the catalog department, and the present stack has reached the saturation point. Partly in an attempt to relieve stack congestion and partly to protect irreplaceable sets from possible bomb damage, some twenty-three thousand volumes of littleused sets in runs before 1900 were moved to the basement of the administration building. This material is available for use if we have twenty-four-hour notice. This shift relieved the tense situation momentarily, but the space acquired has 
now been filled by new acquisitions. Furthermore, removal of this material meant shifting the entire contents of the stack, work which had to be done by girls. It proved to be entirely too heavy for them and will not be attempted again except in case of dire necessity.

The bound newspaper shelves have been badly overcrowded for the past two years. Space on the third floor of California Hall has been allotted to the library, and ways and means are now being considered of transferring material there in order to provide additional newspaper space in the stack. Since there is no elevator in California Hall, any shift will have to be made entirely by hand. The material must be carried to California Hall and up the stairs in lug boxes. The physical problems are tremendous and will require study and ingenuity to solve.

In contrast to the drop in circulation over the desk is the increase in several other types of service. War has had a noticeable influence on the number and kind of special borrower's privilege cards taken out. Many more industrial 'firms in the San Francisco Bay area have taken out borrower's cards than ever before, and most of these firms make extensive use of the library facilities. Local branches of government agencies such as the Office of War Information, Army Map Service, Alameda Naval Air Station, and many others descended on us in a flood soon after Pearl Harbor, requesting library privileges. Many special procedures in handling these cases had to be worked out since each agency presented an individual problem. It is interesting to note that after about two years of intensive use of the library by these agencies, during the last few months demand for material has fallen off markedly.

\section{Interlibrary Loans}

It is also interesting to note the effect of the war on interlibrary loans. We have done much borrowing from other libraries for members of our faculty and for the staff of the radiation laboratory. In 1942-43 we borrowed 822 volumes as compared with 735 during the preceding year. The number of books borrowed from us by other institutions has remained about the same in number, 2400 last year as compared with 2500 the year before, but the type of books wanted shows the influence of the war. The trend is away from literature and history and toward concentration on scientific items, with special interest shown in Russian periodicals and books. In addition to the usual loans to university and public libraries, we are lending more and more to libraries of industrial firms, Army camp libraries, and government agencies all over the country. The Japanese resettlement centers have asked for many books, and several shipments have been sent to the camps for the use of the Evacuation and $\mathrm{Re}$ settlement Survey. The Topaz Relocation Center in Utah has borrowed books on everything from "How to play chess" to "How to build a sewage system." In addition to much regular interlibrary loan material, we have sent about three hundred volumes, other copies or editions of which are available on the campus, on a permanent or "duration" loan to a large government research project in New Mexico.

In addition to the interlibrary loans, our work for microfilm and photostat orders handled through the librarian's office has increased many times over. We check and collect the references on requests sent out to us from the office; the increase during the past year and a half 
has been staggering. The outstanding feature of this work is the tremendous increase in reproductions made for industrial firms engaged in war work and for government agencies.

\section{Reserved Book Room}

In the reserved book room the drop in circulation has been most marked, amounting to about 75 per cent since I940. This may be attributed to the change in emphasis from cultural courses with long reading lists to those requiring more factual or scientific material. Then, too, supplementary reading is much more easily obtainable for two-week use through the loan desk than formerly. However, additional tasks have been assumed: administration of Navy R.O.T.C. books, about three hundred volumes; of books on the Far East for the A.S.T.U.; and of a sizeable collection of supplemental reading for other A.S.T.U. courses.

It is interesting to note that the rental service has shown the smallest circulation drop of any unit of the division. This is probably due to the facts that most students seem to have more money to spend than formerly and that more of them are working on part-time jobs and find they have much less time to read in the library. Since the demand for additional copies of titles on collateral reading lists has dropped off and few new items are being added by instructors, rental service has spent little during the past eighteen months on new acquisitions. The sum accumulated during this period will provide a backlog to cushion the shock of heavy purchases which will undoubtedly have to be made after the war.

The library extension service, which provided books on a rental basis to extension division students, was discontinued last October. The collection used for this purpose is being gradually transferred to the Associated Students Store, which will continue to send books to extension students but on a purchase rather than a rental basis. The reasons for discontinuance were primarly the difficulties of administration and the failure of the service to pay its own way. Many books had to be written off as losses because of the impossibility of tracing the many extension students called into the armed forces. We feel that the Associated Students Store will handle the whole problem with results more satisfactory to all concerned.

In spite of a reduced budget, personnel difficulties, and an increase in some services, we have been doing our best to keep the division functioning. in a normal and efficient manner, doing what we can to provide the government agencies, industrial firms working on war contracts, members of our faculty, and our students with the best service possible under present conditions. 